\title{
МОРФОЛОГО-АНАТОМІЧНЕ ВИВЧЕННЯ ПІДЗЕМНИХ ОРГАНІВ СМИКАВЦЯ ÏCTIBНОГО (ЧУФИ) CYPERUS ESCULENTUS L.
}

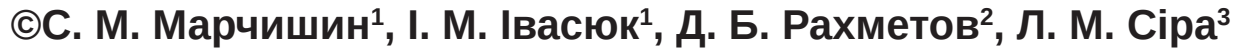 \\ ДВНЗ «Тернопільський державний медичний університет імені І. Я. Горбачевського \\ МОЗ України» ${ }^{1}$ \\ Національний ботанічний сад імені М. М. Гришка НАН України², Київ \\ Національний фрармацевтичний університет³, Харків \\ svitlanafarm@ukr.net
}

\begin{abstract}
Мета роботи. Провести макро- і мікроскопічний аналіз підземних органів смикавця їстівного, запропонованого відділом нових культур НБС НАН України імені М. М. Гришка.

Матеріали і методи. Мікропрепарати виготовляли з підземних органів чуфи, фріксованих у суміші спирт-гліцеринвода (1:1:1) і досліджували загальноприйнятими методами з використанням мікроскопа Item: PB-2610, фротофріксацію результатів здійснювали фоотокамерою Samsung PL50.

Результати й обговорення. Вегетативні й генеративні надземні пагони численні, моноциклічні. Підземні органи мичкувата коренева система, столони та довгі плагіотропні кореневища. Вони наростають симподіально і несуть редуковані лускоподібні листки, додаткові корені і бульби, які розвиваються на кінцевій стадії кущіння із здутих верхівкових частин пагонів. На одній особині може бути до 400 бульб. Бульби округлі, овальні або видовженоовальні, інколи вигнуті; завдовжки 2,5-3,0 см і завширшки 1,0-3,0 см. Вкриті бульбочки жовто-бурою борозенчастозморшкуватою шкіркою.

Кореневища безпучкової будови, з добре розвиненою пухкою паренхімою кори, що запасає крохмаль, частково зруйнованими центральною і перимедулярною зонами, щільним вузьким кільцем провідних тканин, відділеним від кори великоклітинною ендодермою.

Придаткові корені кореневищ і бульб дуже тонкі, темні, мають первинну будову. Мезодерма первинної кори складається з великих лопатевих клітин, що містять крохмальні зерна. Екзодерма характеризується неоднорідністю; містить клітини з темно-коричневим вмістом, поодинокі механічні волокна та клітини з ефірною олією. Ендодерма чітко відділяє кору від центрального циліндра, клітини якої великі, овальні, часто серед них знаходяться клітини 3 темним секретом. В осьовому циліндрі молодих коренів виявляється 7-8-архний радіальний пучок і склеренхіма у центрі.

Бульби вкриті тонким шаром перидерми, яка включає окорковілі клітини та секреторні ідіобласти 3 коричневим вмістом. Під покривною тканиною лежить до 5-6 шарів видовжених лежачих склереїд, глибше - кілька шарів брахісклереїд із здерев'янілими пористими оболонками та 2-3 шари склереїдів із целюлозними оболонками. Ідентифріковано і підтверджено якісними мікрореакціями накопичення жирної олії, великих простих крохмальних та дрібних простих алейронових зерен. Кільце камбіальних клітин ущільнене, вузьке. Утворені неповні провідні пучки та відокремлені тяжі судин і трахеїдів розсіюються по паренхімі кори і осьового циліндра.

Висновки. Досліджено морфолого-анатомічну будову підземних органів смикавця їстівного (чуфри). Виявлено основні макро- і мікроскопічні діагностичні ознаки кореневищ, коренів, бульб, які будуть використані для розробки методів контролю якості на нову лікарську рослинну сировину.
\end{abstract}

Ключові слова: смикавець їстівний (чуфа); кореневище; корені; бульби; морфолого-анатомічна будова; діагностичні ознаки.

Вступ. Родина Суреraceae - одна з найбільш визнаних родин світової фрлори, а у складі класу Liliopsida Batsch вона займає третє місце після Orchidaceae Juss. I Poaceae Barnhart [1, 2]. За даними різних авторів [3-6], до неї зараховують від 70 до 120 родів і від 4000 до 5600 видів [2].

Єдиний культурний вид роду Cуреrus - Cyperus esculentus L. - харчова, олійна, крохмаленосна рос- лина з високими дієтичними та цілющими властивостями

Cyperus esculentus L. (смикавець їстівний, чуфра, земляний мигдаль) (рис. 1) - багаторічний, світловий полікарпик родини осокові (Суреraceae) підродини Суреroideae, здатний утворювати нещільні дернини по низинних, сирих, болотистих місцях, у долинах і заплавах річок. 3 давніх часів рослина культивується

ISSN 2312-0967. Фармацевтичний часопис. 2018. № 3 
на Закавказзі, Середземномор'ї, Центральній Азії, акліматизована та районована на півдні України (Одеська область), вирощується у ботанічних садах. Чуфа визнана цінною технічною, харчовою, кормовою культурою, завдяки своїй декоративності популярна в ландшафртному дизайні.

У себе на батьківщині смикавець їстівний - багаторічна рослина, на другий рік життя цвіте і плодоносить. Суцвіття зонтикоподібне, довжина променів суцвіття - 1-10 см. Покривні луски солом'яно-жовті. Плоди-горішки - червонувато бурі, блискучі. В умовах України при вирощуванні у відкритому ґрунті рослина майже ніколи не утворює квіткові пагони, тому розмножується бульбочками [7, 8].

У джерелах наукової літератури відсутня інфрормація про морфолого-анатомічне вивчення смикавця їстівного, тому метою наших досліджень було провести макро- і мікроскопічний аналіз підземних органів смикавця їстівного, запропонованого відділом нових культур НБС НАН України імені М. М. Гришка, де на базі Національного ботанічного саду тривають селекційні роботи з отримання перспективних клонів двох сортів чуфри української селекції.

Матеріали і методи. Мікропрепарати виготовляли з підземних органів чуфи, фріксованих у суміші спиртгліцерин-вода (1:1:1) [9, 10] і досліджували загальноприйнятими методами 3 використанням мікроскопа Item PB-2610, фротофріксацію результатів здійснювали фотокамерою Samsung PL50.

Результати й обговорення.

Морфологічна будова підземних органів Cyperus esculentus L.

Вегетативні й генеративні надземні пагони численні, моноциклічні. Підземні органи - мичкувата коренева система, столони та довгі плагіотропні кореневища. Вони наростають симподіально і несуть редуковані лускоподібні листки, додаткові корені і бульби (бульбочки), які розвиваються на кінцевій стадії кущіння із здутих верхівкових частин пагонів. Внаслідок утворення таких спеціалізованих підземних органів особини вегетативно рухливі, розростаються на значній площі фрітоценозу. На одній особині може бути до 400 бульб. Бульби округлі, овальні або видовжено-овальні, інколи вигнуті (рис. 1). Залежно від умов зростання змінюється маса бульбочок, розміри у середньому дорівнюють завдовжки 2,5-3,0 см і завширшки 1,03,0 см. Вкриті бульбочки жовто-бурою шкіркою, невіддільною від білої м'якоті. Шкірка борозенчасто-зморшкувата, світло-коричнева або буро-темно-коричнева, з 3-5 паралельними кільцями борозенок (вузлів) з дуже дрібними корінцями.

Анатомічна будова підземних органів Cуреrus esculentus L.

Кореневища (рис. 2) безпучкової будови, з добре розвиненою пухкою паренхімою кори, що запасає крохмаль, частково зруйнованими центральною і перимедулярною зонами, щільним вузьким кільцем провідних тканин, відділеним від кори великоклітинною ендодермою. Перидерма 3 кількома шарами опробковілих клітин. Збільшення розмірів кореневищ відбувається за рахунок інтенсивного розростання паренхіми.

Придаткові корені (рис. 3) кореневищ і бульб дуже тонкі, темні, мають первинну будову. Мезодерма первинної кори пухка, складається з дуже крупних лопатевих клітин, що містять крохмальні зерна, та об'ємних міжклітинних просторів. Екзодерма зазвичай легко відділяється. Характеризується шаруватістю та неоднорідністю: превалюють прямокутні або округлі клітини з трохи потовщеними окорковілими оболонками. Серед них довільно розміщені клітини 3 темно-коричневим вмістом, а також поодинокі механічні волокна та клітини 3 ефрірною олією. Ендодерма чітко відділяє кору від центрального циліндра, оточеного 1-2-шаровим механічним кільцем склеренхіми. Клітини ендодерми великі, овальні, часто серед них знаходяться клітини 3 темним секретом. В осьовому циліндрі молодих коренів виявляється 7-8-архний радіальний пучок і склеренхіма у центрі. У старіючих коренях ділянки фрлоеми і ксилеми поліархного радіального пучка зближені, відмежовані невиразно і утворюють щільний про-
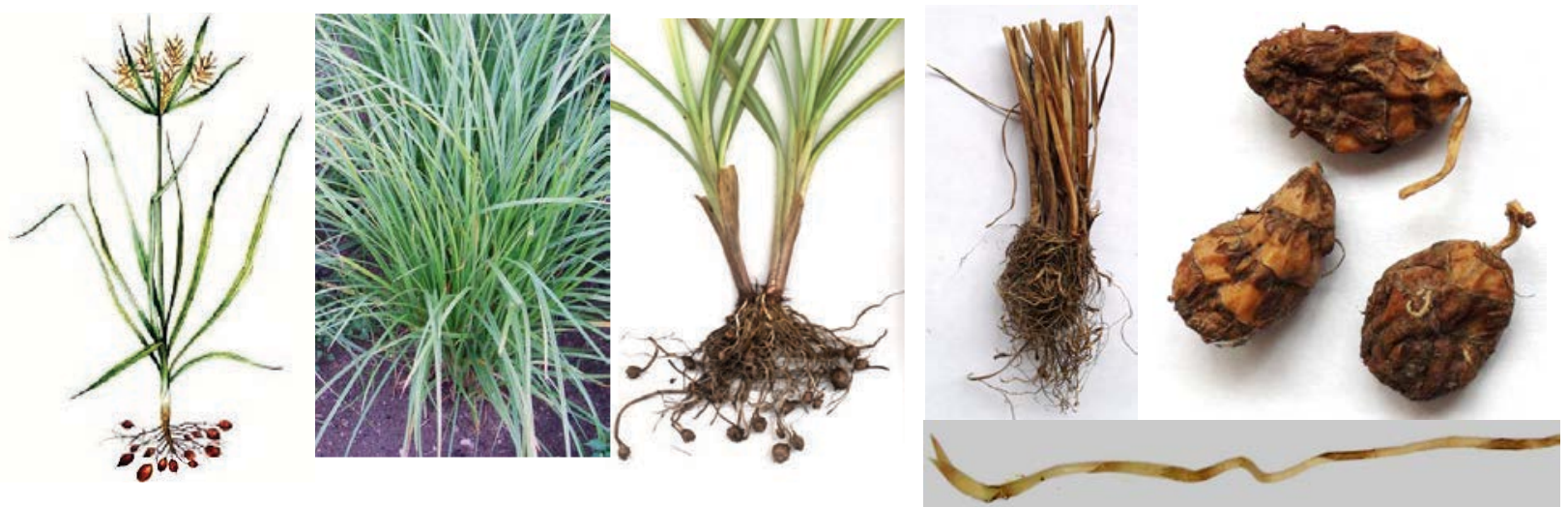

Рис. 1. Зовнішній вигляд, бульби та кореневище Cyperus esculentus.

ISSN 2312-0967. Pharmaceutical review. 2018. № 3 
Фітохімічні дослідження Phytochemical researches

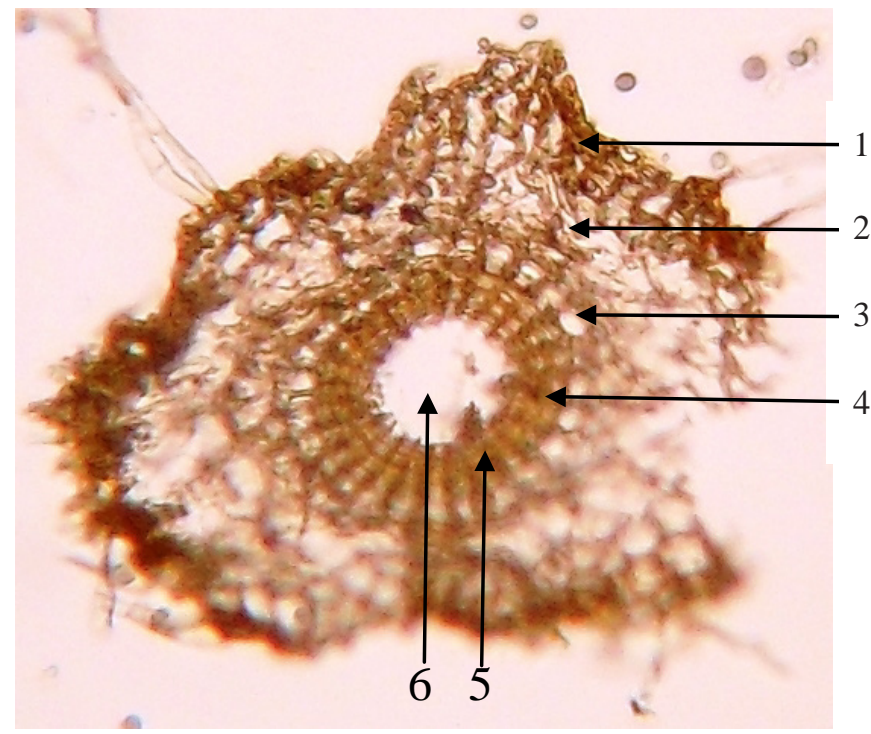

Рис. 2. Поперечний зріз кореневища середньої товщини: 1 - перидерма, 2 - запасаюча паренхіма кори, 3 - ендодерма, 4 - фрлоема, 5 - ксилема, 6 - зруйнована серцевина.
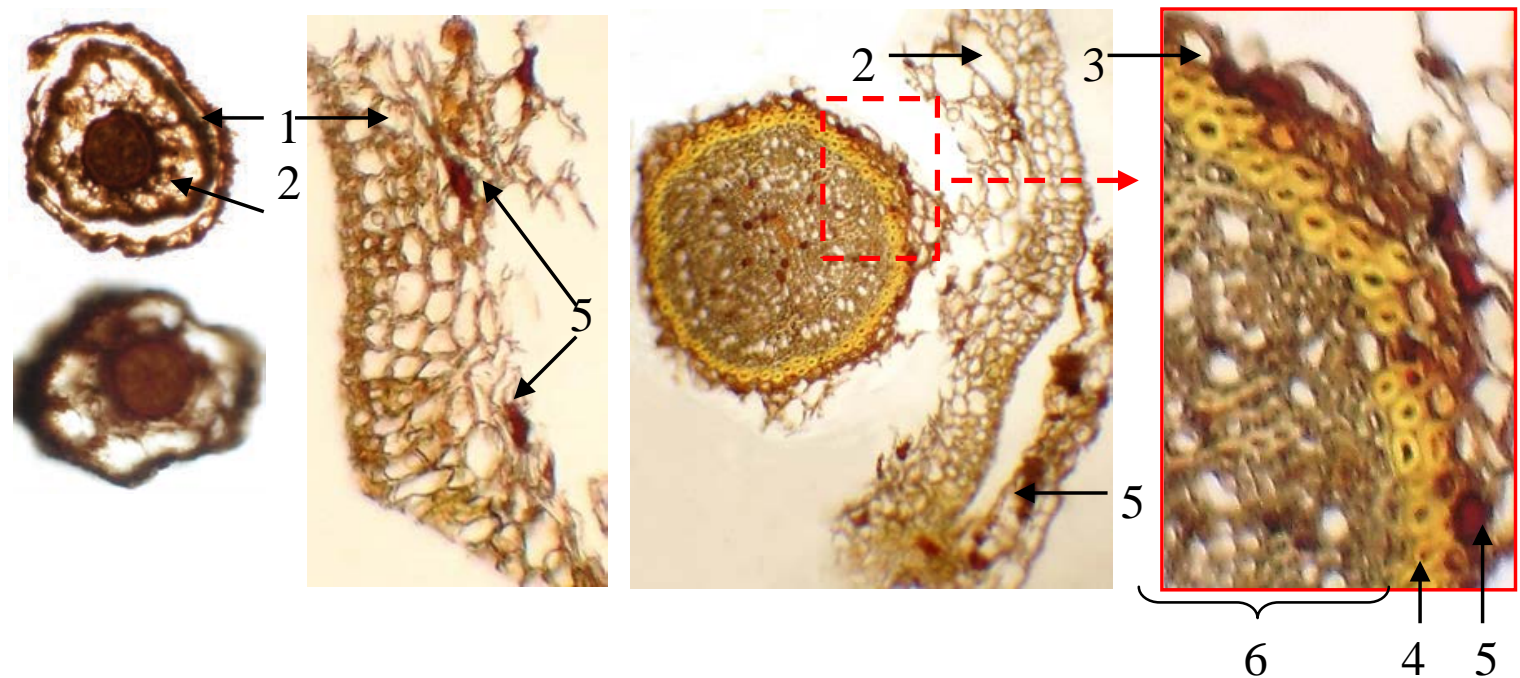

Рис. 3. Поперечні зрізи коренів (X4, X10): 1 - екзодерма, 2 - мезодерма, 3 - ендодерма, 4 - склеренхіма, 5 - пігментовані ідіобласти, 6 - провідні й механічні елементи центрального циліндра.

відний циліндр. Він включає вузькі трахеїди, судини, ксилемні волокна, пігментовані клітини паренхіми та дрібні ситоподібні трубки. У старих коренях відбувається поступова облітерація та руйнація елементів фрлоеми.

Бульби (рис. 1, 4, 5) вкриті тонким шаром перидерми, яка включає окорковілі клітини та секреторні ідіобласти з коричневим вмістом. Під покривною тканиною нараховується до 5-6 шарів видовжених лежачих склереїдів, глибше - кілька шарів брахісклереїдів із здерев'янілими пористими оболонками та 2-3 шари склереїдів із целюлозними оболонками. Клітини периферійних шарів запасаючої тканини мають потовщені оболонки, а клітини, що ближче до центру і складають основну масу органа, - тонкостінні. Ідентифріковано і підтвер- джено якісними мікрореакціями накопичення жирної олії, великих простих крохмальних та дрібних простих алейронових зерен. Кільце камбіальних клітин ущільнене, вузьке, але чітко відділяє більш розрослу корову частину від центрального осьового циліндра. В міру стовщення бульб ситоподібні трубки і судини руйнуються, роздрібнюються. Утворені неповні провідні пучки та відокремлені тяжі судин і трахеїдів (рис. 4) розсіюються по паренхімі кори і осьового циліндра.

На поперечних зрізах бульб добре помітні зачатки придаткових корінців та чітко відмежовані тканини вічок (рис. 5) різної стадії розвитку. Вони захищені лусочками, в яких розвинені тяжі склеренхіми, а серед паренхіми багато секреторних клітин 3 жовто-оранжевим вмістом. У борозенчастих кільцях бульб, що

ISSN 2312-0967. Фармацевтичний часопис. 2018. № 3 


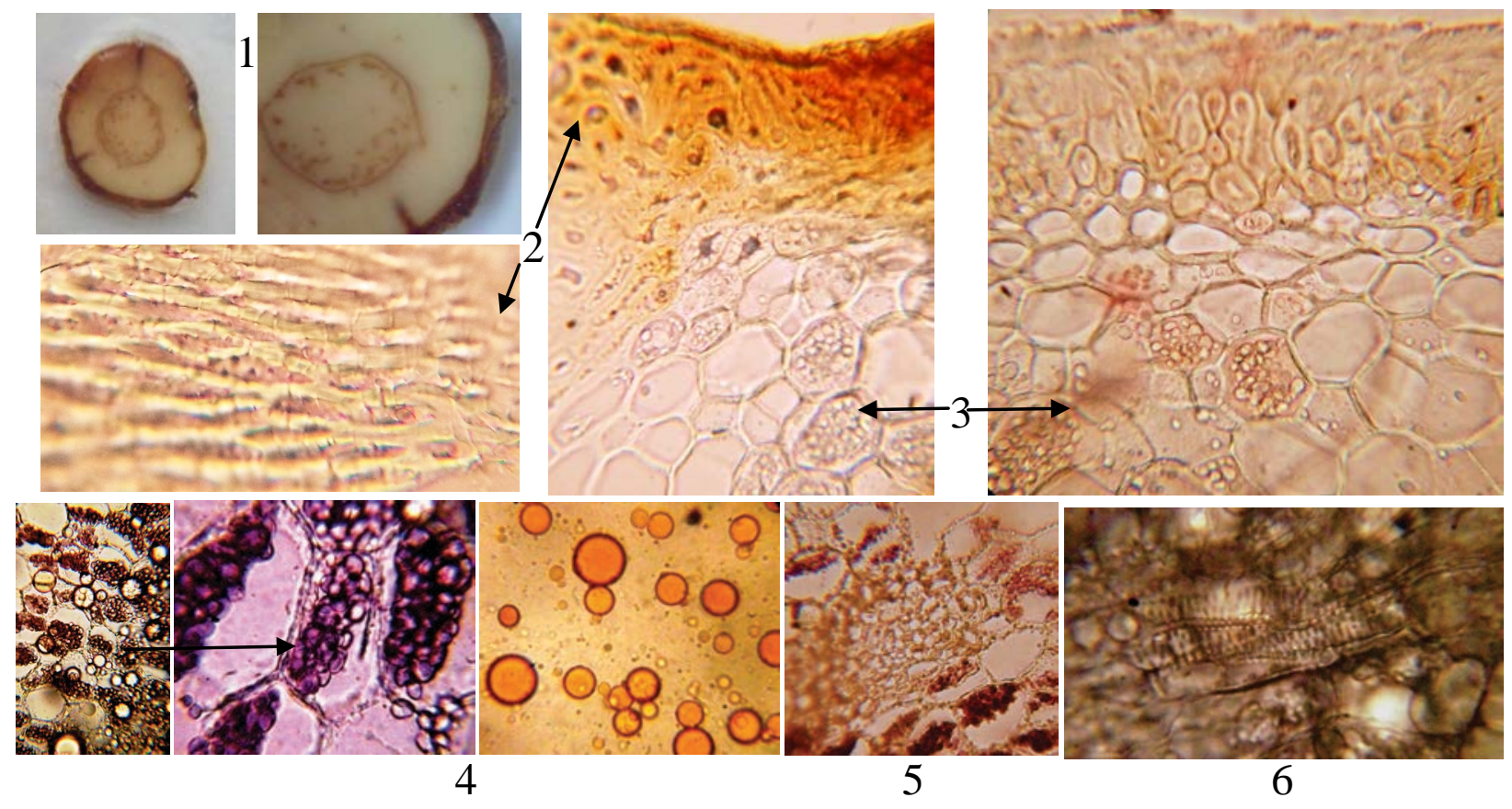

Рис. 4. Фрагменти зрізів бульби чуфи: 1 - поперечні зрізі у плані, 2 - склереїди на поперечному і поздовжньому зрізах, 3 - паренхіма кори, 4 - крохмальні зерна, забарвлені розчином Люголя, та краплі жирної олії, забарвлені суданом III, 5 - неповний провідний пучок, 6 - відокремлені тяжі трахеїдів.
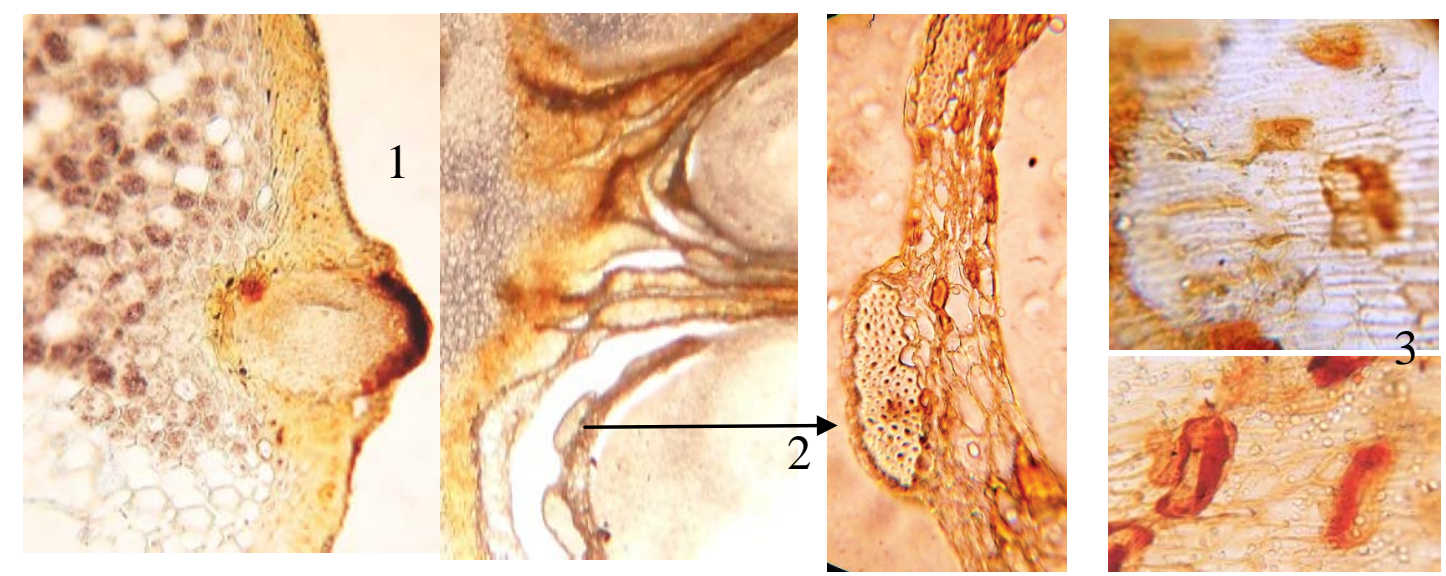

Рис. 5. Поперечні зрізи бульб із вічками $(1,2)$ та плівчасті листочки бульб із поверхні (3).

відповідають вузлам видозміненого пагона, знаходяться листки, видозмінені до бурих плівочок (рис. 5). На препаратах з поверхні в них серед прямокутних, ледь видовжених клітин епідерми і паренхіми, знаходяться ідіобласти з яскравим червоно-коричневим вмістом.
Висновки. Досліджено морфолого-анатомічну будову підземних органів смикавця їстівного (чуфи). Виявлено основні макро- і мікроскопічні діагностичні ознаки кореневищ, коренів, бульб, які будуть використані для розробки методів контролю якості на нову лікарську рослинну сировину. 
Фітохімічні дослідження

Phytochemical researches

\title{
МОРФОЛОГО-АНАТОМИЧЕСКОЕ ИЗУЧЕНИЕ ПОДЗЕМНЫХ ОРГАНОВ СЫТИ СЪЕДОБНОЙ (ЧУФЫ) (CYPERUS ESCULENTUS L.)
}

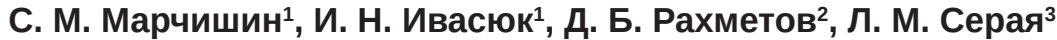 \\ ГВУЗ «Тернопольский государственный медицинский университет имени И. Я. Горбачевского МЗ \\ Украины» ${ }^{1}$
}

Национальний ботанический сад имени Н. Н. Гришко НАН Украины, Киев²

Национальный фрармацевтический университет, Харьков ${ }^{3}$

svitlanafarm@ukr.net

Цель работы. Провести макро- и микроскопический анализ подземных органов сыти съедобной, предложенной отделом новых культур НБС НАН Украины имени Н. Н. Гришко.

Материалы и методы. Микропрепараты изготавливали из подземных органов чуфы, фриксировали в смеси спиртглицерин-вода (1:1:1) и исследовали общепринятыми методами с использованием микроскопа Item: PB-2610, фротофиксацию результатов осуществляли фротокамерой Samsung PL50.

Результаты и обсуждение. Вегетативные и генеративные надземные побеги многочисленные, моноциклические. Подземные органы - мочковатая корневая система, столоны и длинные плагиотропные корневища. Они нарастают симподиально и несут редуцированные чешуевидные листья, дополнительные корни и клубни, которые развиваются на конечной стадии кущения со сдутых верховых частей побегов. На одной особи может быть до 400 клубней. Клубни округлые, овальные или удлиненно-овальные, иногда изогнутые; длиной 2,5-3,0 см и шириной 1,0-3,0 см. Покрытые клубеньки желто-бурой, борозенчасто-морщинистой кожурой.

Корневища безпучкового строения, с хорошо развитой рыхлой паренхимой коры, запасающей крахмал, с частично разрушенными центральной и перимедулярной зонами, плотным узким кольцом проводящих тканей, отделенных от коры крупноклеточной эндодермой.

Придаточные корни корневищ и клубней очень тонкие, темные, имеют первичную структуру. Мезодерма первичной коры состоит из крупных лопастных клеток, содержащих крахмальные зерна. Экзодерма характеризуется неоднородностью; содержит клетки с темно-коричневым содержимым, единичные механические волокна и клетки с эфирным маслом. Эндодерма четко отделяет кору от центрального цилиндра, клетки которой крупные, овальные, часто среди них находятся клетки с темным секретом. В осевом цилиндре молодых корней расположен 7-8-архный радиальный пучок и склеренхима в центре.

Клубни покрыты тонким слоем перидермы, которая включает опробковевшие клетки и секреторные идиобласты с коричневым содержимым. Под покровной тканью лежит 5-6 слоев удлиненных склереидов, глубже - несколько слоев брахисклереидов с одревесневшими пористыми оболочками и 2-3 слоя склереидов с целлюлозными оболочками. Идентифицировано и подтверждено качественными микрореакциями накопление жирного масла, больших простых крахмальных и мелких простых алейроновых зерен. Кольцо камбиальных клеток уплотненное, узкое. Неполные проводящие пучки и отдельные тяжи сосудов и трахеид рассеиваются по паренхиме коры и осевого цилиндра.

Выводы. Исследовано морфолого-анатомическое строение подземных органов сыти съедобной (чуфы). Выявлены основные макро- и микроскопические диагностические признаки корневищ, корней, клубней, которые будут использованы для разработки методов контроля качества на новое лекарственное растительное сырье.

Ключевые слова: сыть съедобная (чуфа); корневище; корни; клубни; морфолого-анатомическое строение; диагностические признаки.

\section{MORPHOLOGICAL AND ANATOMIC STUDY OF SUBTERRANEOUS ORGANS OF YELLOW NUT GRASS (CHUFA) CYPERUS ESCULENTUS L.}

\author{
S. M. Marchyshyn ${ }^{1}$, I. M. Ivasiuk ${ }^{1}$, D. B. Rakhmetov ${ }^{2}$, L. M. Sira ${ }^{3}$ \\ I. Horbachevsky Ternopil State Medical University ${ }^{1}$ \\ M. Hryshko National Botanic Garden of the NAS of Ukraine², Kyiv \\ National University of Pharmacy ${ }^{3}$, Kharkiv \\ svitlanafarm@ukr.net
}

The aim of the work. Conducting a macro- and microscopic analysis of the subterraneous organs of the yellow nut grass, proposed by the Department of New Cultures of M. Hryshko National Botanic Garden of the National Academy of Sciences of Ukraine.

ISSN 2312-0967. Фармацевтичний часопис. 2018. № 3 
Materials and Methods. The micronutrients were made from subterraneous organs of chufa fixed in a mixture of alcoholglycerine-water (1:1:1) and studied by conventional methods using the microscope Item: PB-2610, and photofixation of the results was made by the Samsung PL50 camera.

Results and Discussion. Vegetative and generative above ground shoots are numerous, monocyclic. Subterraneous organs are a fibrous root system, stolons and long plagyotropic rhizomes. They grow sympathetically and carry reduced squamous leaves, additional roots and tubers, which develop at the final stage of tillering from the blown apical parts of the shoots. One plant unit can have up to 400 tubers. Tubers are round, oval or elongated oval, sometimes curved; with a length of $2.5-3.0 \mathrm{~cm}$ and a width of $1.0-3.0 \mathrm{~cm}$. Tubers are covered with yellow-brown, furrow-wrinkled peel.

Rhizomes of without bundled structure with a well developed puff parenchyma of the cortex that stores starch, partially destroyed by the central and perimedullary zones, a dense narrow ring of conducting tissues, separated from the cortex by the large cell endoderm.

The adventitious roots of rhizomes and tubers are very thin, dark, have a primary structure. The mesoderm of the primary cortex consists of large lobate cells containing starch grains. Exoderm is characterized by heterogeneity; contains cells with dark brown content, single mechanical fibers and cells with essential oils. The endoderma clearly separates the cortex from the central cylinder, the cells of which are large, oval, often among them there are cells with dark secretion. In the axial cylinder of young roots there is a 7-8-arch radial bundle and sclerenchyma in the center.

Tubers are covered with a thin layer of periderm, which includes cortical cells and secretory idioblast with brown content. Under the covering tissue there are up to 5-6 layers of elongated lying sclereids, more deeply - several layers of brachysclereids with lignified porous membranes and 2-3 layers of sclereids with cellulose membranes. We identified and confirmed by high-quality micro reactions the accumulation of oily oil, large simple starch and small simple aleuroneic grains. The ring of cambial cells is compact, narrow. The resulting incomplete conductive bundles and separated strains of the vessels and tracheaids are scattered along parenchyma cortex and axial cylinder.

Conclusions. The morphological and anatomical structure of the subterraneous organs of the yellow nut grass (chufa) is investigated. The main macroscopic and microscopic diagnostic features of rhizomes, roots, tubers, which will be used for the development of quality control methods for new medicinal plant material, were revealed.

Key words: yellow nut grass (chufa); rhizome; roots; tubers; morphological and anatomical structure; diagnostic features.

\section{Список літератури}

1. Тахтаджян А. Л. Система магнолиофитов / А. Л. Тахтаджян. - М. : Наука, 1987. - 439 с.

2. Данилик І. М. Система родини фрлори України / І. М. Данилюк // Український ботан. журнал. - 2012. T. 69, № 3. - С. 337 - 351.

3. Kükenthal G. Cyperaceae-Caricoideae // A. Engler, Pflanzenreich. - Leipzig: Verlag von Wilhelm Engelmann, 1909. - Bd. 4, h. 20. (Heft 38). - 884 s.

4. Kükenthal G. Cyperaceae-Scirpoideae-Cypereae // Pflanzenreich, IV. 20 / A. Engler editor. ed. - Leipzig: Verlag von Wilhelm Engelmann, 1935-1936. - Bd. 4, h. 20. (Heft 101). $-671 \mathrm{~s}$.

5. Phylogeny of Cyperaceae based on DNA se qu ence data: Current progress and future prospects / F. M. Muasya, D. A. Simpson, G. A. Verboom [et al.] // Bot. Rev. - 2009. Vol. 75. - P. 2-21.

6. Phylogeny of Cyperaceae based on DNA sequence data - a new rbcL analysis / D. A. Simpson, A. M. Muasya,

\section{References}

1. Takhtadzyan AL. Magnoliofit system. [Система магнолиофитов] Moscow: Nauka; 1987. Russian.

2. Danylyk IM. [System of the family of flora of Ukraine]. Ukr botan zhurn. 2012;69(3): 337-51. Ukrainian.

3. Kükenthal G. Cyperaceae-Caricoideae. Pflanzenreich. Leipzig: Verlag von Wilhelm Engelmann; 1909.

4. Kükenthal G. Cyperaceae-Scirpoideae-Cypereae. Pflan-
M. V. Alves [et al.] // Aliso. - 2007. - Vol. 23. - P. 72-83.

7. Чабан Л. В. Новий сорт смикавця їстівного (чуфи) Запас / Л. В. Чабан, О. В. Позняк // Овочівництво і баштанництво - 2013. - Вип. 59. - С. $279-282$.

8. Позняк О. В. Сорт смикавця їстівного (чуси) овочевого напрямку використання Запас / О. В. Позняк, Л. В. Чабан // Овочівництво України. Наукове забезпечення і резерви збільшення виробництва товарної продукції та насіння: збірник тез Міжнар. наук.-практ. конф. (26 липня 2012 р., м. Харків, Інститут овочівництва і баштанництва НААН). - Харків : ТОВ «Виробниче підприємство «Плеяда», 2012. - С. $79-81$.

9. Справочник по ботанической микротехнике. Основы и методы / [Р. П. Барыкина, Т. Д. Веселова, А. Г. Девятов и др.]. - М. : Изд-во МГУ, 2004. - 312 с.

10. Фурст Г. П. Методы анатомо-гистохимического исследования растительных тканей / Г. П. Фурст. - М. : Наука, 1979. - 154 с.

zenreich, IV. 20. A. Engler editor. ed. Leipzig: Verlag von Wilhelm Engelmann.

5. Muasya FM, Simpson DA, Verboom GA. Phylogeny of Cyperaceae based on DNA se qu ence data: Current progress and future prospects. Bot Rev. 2009;75: 2-21.

6. Simpson DA, Muasya AM, Alves MV. Phylogeny of Cyperaceae based on DNA sequence data - a new rbcL anal-

ISSN 2312-0967. Pharmaceutical review. 2018. № 3 


\section{ysis. Aliso. 2007;23: 72-83.}

7. Chaban LV, Pozniak LV. [A new sort of yellow nut grass (chufa). Stock]. Ovochivnyts i bashtannyts. 2013;59: 27982. Ukrainian.

8. Pozniak OV, Chaban LV. A sort of yellow nut grass (chufa) of the vegetable direction of use. Stock. Vegetable farming of Ukraine. Scientific support and reserves for increasing the production of commodity products and seeds: a collection of theses of International Science-Practical Conference, 2012 July 26; Kharkiv. Institute of Horticulture and Melons-growing of NAAS. Kharkiv: Pleiada Production Enterprise Ltd.; 2012. p. 79-81. Ukrainian.

9. Barykina RP, Veselova TD, Devyatov AG. Guide to botanical microtechnology. Bases and methods. [Справочник по ботанической микротехнике. Основы и методы] Moscow: Izd-vo MGU; 2004. Russian.

10. Furst GP. Methods of anatomo-histochemical study of plant tissues. [Методы анатомо-гистохимического исследования растительных тканей] Moscow: Nauka; 1979. Russian. 